http://garmian.edu.krd

https://doi.org/10.24271/garmian.150

\title{
Effect of casein hydrolysate and paclobutrazol on embryogenesis of date palm (Phoenix dactylifera L.) cv. Nersy by in vitro culture
}

\author{
Majid Abdulhameed IBRAHIM*1 ${ }^{1}$, Huda A. AL-TAHA ${ }^{2}$, Zyad Tariq AL-ALI $^{3}$ \\ Department of Horticulture and Landscape Design, College of Agriculture \\ University of Basra, Basra, Iraq \\ *1 For corresponding: e-mail: majidalbassiri@ yahoo.com \\ 2 taha_altaha@yahoo.com \\ 3 zyadalali@yahoo.com
}

\begin{abstract}
Results showed that fresh and dry weight of primary and embryogenic callus increased significant with increasing of casein or paclobutrazol after 16 weeks from culture. The treatments of $1000 \mathrm{mg} . \mathrm{L}^{-1}$ casein hydrolysate and $0.5 \mathrm{mg} . \mathrm{L}^{-1}$ paclobutrazol showed fewer periods to embryo formation reached 21.00 and 17.00 days, respectively. However, the control observed the longest period to somatic embryo formation which reached 61.00 days. The treatments of $1000 \mathrm{mg} . \mathrm{L}^{-1}$ casein hydrolysate and $1.0 \mathrm{mg} . \mathrm{L}^{-1}$ paclobutrazol showed the highest values 6.50 and 1.60 cm length, 0.87 and $0.80 \mathrm{~cm}$ diameter, 0.336 and $0.361 \mathrm{gm}$ fresh weight and, 0.022 and 0.033 gm dry weight of embryo's characteristics, respectively. In addition, two treatments of paclobutrazol $\left(0.5\right.$ and $\left.0.7 \mathrm{mg} . \mathrm{L}^{-1}\right)$ showed high average number of embryos (16.33 and 16.67 embryos, respectively). In contrast, the recorded data from the control treatment gave demonstrated fewer values $(4.33$ embryos, $0.80 \mathrm{~cm}$ length, $0.13 \mathrm{~cm}$ diameter, $0.035 \mathrm{gm}$ fresh weight and $0.005 \mathrm{gm}$ dry weight) of characteristics of embryos. When the culture medium contained casein hydrolysate at $1000 \mathrm{mg} . \mathrm{L}^{-1}$ observed the highest percentage of germination $(76 \%)$ and less period of embryo germination (15.30) days in comparison with other treatments. Moreover, the culture medium with low concentration of paclobutrazol $\left(0.3 \mathrm{mg} . \mathrm{L}^{-}\right.$ ${ }^{1}$ ), showed the highest percentage of germination $(75.67 \%)$ in comparison with other treatments of paclobutrazol. However, the same concentration of paclobutrazol obtained the lowest period of embryo germination (14.0 days) in comparison with the other treatments. The results also showed that the callus when cultured on MS medium supplemented with 800 or $1000 \mathrm{mg} . \mathrm{L}^{-1}$ casein hydrolysate demonstrated indirect adventitious shoots.
\end{abstract}

Key words: casein hydrolysate; embryogenesis; germination; In vitro; organogenesis; paclobutrazol; Phoenix dactylifera.

*For corresponding: e-mail: majidalbassiri@yahoo.com 


\section{Abbreviations:}

2iP: Isopentenyl adenine.

MS: Murashige and Skoog salts (Murashige and Skoog, 1962).

NAA: $\alpha$-naphthalene acetic acid.

Paclobutrazol: $\beta-(4$-chlorophenyl)methyl -( 1,1-dimethylethyl) -1Hl, 2,4-triazole1-ethanol.

\section{INTRODUCTION}

The date palm tree belongs to the fruit trees of the evergreen that follow the Arecaceae family (Al-Khalifa, 2007). The original home of these trees is southern Iraq. These trees were propagated in two methods, the first are the sexual method by seeds. The disadvantage of this method is to obtain heterogeneity in the genetic characteristics from the mother plant. The second method is the traditional vegetative propagation by offshoots (Al-Baker, 1972). Disadvantages of this method are the small number of offshoots per a tree. As a result of these problems that prevents the propagation of date palm trees through sexual and vegetative propagation. Due to these problems many researchers resorted to the tissue culture of the date palm trees. One method to of plant tissue culture is to indirect embryogenesis from induced callus (Muter, 1991). Rudus et al. (2002) studied the effect of adding several concentrations of paclobutrazol $(0,50$ or $100 \mu \mathrm{mol})+5$ mg. $L^{-1} 2,4-D+1$ mg. $L^{-1}$ kinetin to MS medium. As they found that the concentration of paclobutrazol $(100 \mu \mathrm{mol})$ is better in embryogenesis of alfalfa plant and increases their number compared to the treatment of control. Piqueras et al. (1999), showed that $0.1 \mathrm{mg} . \mathrm{L}^{-1}$ paclobutrazol led to induction and increasing in fresh weight of callus. They were also able to get adventitious shoots from callus of saffron plant (Crocus sativus), when cultured on MS medium supplemented with 2 mg. $\mathrm{L}^{-1} \mathrm{BA}+0.1 \mathrm{mg} . \mathrm{L}^{-1}$ 2,4-D + 0.0, 0.1, 0.5, 1.0 or $2.0 \mathrm{mg} . \mathrm{L}^{-1}$ paclobutrazol. The $0.1 \mathrm{mg} . \mathrm{L}^{-1}$ concentration of paclobutrazol gave the largest number of adventitious shoots. The same researchers studied on effect of different concentrations of casein

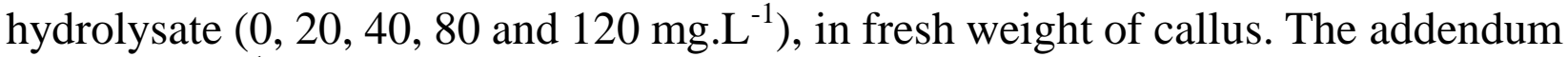
of $120 \mathrm{mg} . \mathrm{L}^{-1}$ casein hydrolysate led to the highest value in fresh weight of callus in comparison to control treatment. Moreover, another study conducted by Ageel \& Elmeer (2011) on the effect of casein hydrolysate (0, 1, 2 and $\left.3 \mathrm{mg} . \mathrm{L}^{-1}\right)$ on the stimulation of embryogenesis of date palm, they were found that the $3 \mathrm{mg} . \mathrm{L}^{-1}$ paclobutrazol led to the formation and increase in number of somatic embryos. The study was conducted to increase of the somatic embryos formation of date palm (Phoenix dactylifara L.) cv. Nersy by adding the casein hydrolysate and paclobutrazol to growth medium. 


\section{MATERIALS AND METHODS}

The experiment was carried out in the Plant Tissue Culture Laboratories, Date Palm Research Centre, Basra University, Basra, Iraq.

Shoot tips $(1.0 \mathrm{~cm})$ of Phoenix dactylifera L. cv. Nersy were obtained from healthy mature trees growing in a private orchard. The shoot tips were then kept in an antioxidant solution containing $100 \mathrm{mg} \mathrm{l}^{-1}$ ascorbic acid and $150 \mathrm{mg} \mathrm{l}^{-1}$ citric acid for $24 \mathrm{~h}$ to avoid phenolic compounds exudation during explants culturing. The shoot tips were rinsed 3 times with sterile distilled water and then surface sterilized with 20\% commercial Chlorax solution (SEHAT Company)containing $1.05 \%$ sodium hypochlorite and a drop of Tween 20 for $15 \mathrm{~min}$. The shoot tips were rinsed in sterile distilled water 3 times.

\section{Effect casein hydrolysate or paclobutrazol on callus, indirect somatic embryo induction and embryo germination}

Shoot tips were cultured on full strength MS basal media (Murashige \& Skoog, 1962), supplemented with either Casein hydrolysate (Control, 0.3, 0.5, 0.7, 0.9 and $\left.1.0 \mathrm{mg} \mathrm{l}^{-1}\right)$ or Paclobutrazol $\left(200,400,600,800\right.$ and $\left.1000 \mathrm{mg} \mathrm{l}^{-1}\right)$, the medium was also supplemented with $170 \mathrm{mg} . \mathrm{L}^{-1}$ Sodium dihydrogen ortho phosphate, $30 \mathrm{gm} . \mathrm{L}^{-}$ 1 Sucrose, $100 \mathrm{mg} . \mathrm{L}^{-1}$ Meso-inositol, $40 \mathrm{mg} . \mathrm{L}^{-1}$ adenine sulphate, $0.5 \mathrm{mg} . \mathrm{L}^{-1}$ Thiamine-HCl, $3000 \mathrm{mg} . \mathrm{L}^{-1}$ and active charcoal. Callus medium was enriched with $2.0 \mathrm{mg} . \mathrm{L}^{-1}$ 2ip and $5.0 \mathrm{mg} . \mathrm{L}^{-1} \mathrm{NAA}$. While, that medium of somatic embryo formation was supplemented with $1.0 \mathrm{mg} . \mathrm{L}^{-1} 2 \mathrm{ip}$ and $1.0 \mathrm{mg} . \mathrm{L}^{-1}$ 2,4-D. $1.0 \mathrm{mg} . \mathrm{L}^{-1}$ 2ip and $0.1 \mathrm{mg} . \mathrm{L}^{-1} 2,4-\mathrm{D}$ were added to the germination medium. The medium was solidified with $0.7 \%$ agar-agar. Finally, $\mathrm{pH}$ of the media was adjusted to 5.7 using 0.1 normality $(\mathrm{N})$ of $\mathrm{NaOH}$ or $\mathrm{HCl}$ after and then autoclaved at $1.04 \mathrm{~kg} . \mathrm{cm}^{-2}$ for 15 min. All media were dispensed into $25 \times 150 \mathrm{~mm}$ test-tubes adding $25 \mathrm{ml}$ medium/tube. Cultures were incubated at a light intensity of 1000 lux provided by white fluorescent lamps for $16 \mathrm{~h}$ photoperiod at $27 \pm 1^{\circ} \mathrm{C}$.

Studied characteristics

1. Fresh and dry weight of primary and embryonic callus

2. Period of embryo formation (days)

3. Number of embryos

4. Length of embryo $(\mathrm{cm})$

5. Diameter of embryo $(\mathrm{cm})$

6. Fresh and dry of embryo (gm)

7. Embryo germination (\%)

8. Period of embryo germination (days) 


\section{Statistical design and analysis}

Completely randomized design was used. Each treatment represented ten replicates. The data was subjected to the analysis of variance and mean values were compared using revised LSD at $5 \%$ (Snedecor \& Cochran 1986).

\section{RESULTS AND DISCUSSION}

\section{Primary and embryogenic callus:}

Results shown in the Table.1 indicate primary and embryogenic callus formation on MS medium supplemented with different concentrations of casein hydrolysate or paclobutrazol after 16 weeks from culture. Results showed that fresh and dry weight of primary and embryogenic callus were significantly increased with increasing concentrations of either casein hydrolysate or paclobutrazol (Plate.1, A, $\mathrm{B}, \mathrm{C}$ and D). The reason for the casein hydrolysate to stimulate the growth and development of callus may either back to cysteine molecule that contains two groups of $\left(-\mathrm{NH}_{2}\right)$, which they play a role in the induction of callus (Anderson, 1978), or the active role of paclobutrazol in stimulation of cell division and the formation, growth and development of callus (Abo-Zaid, 2000), (Table.1 and Plate.1, A, B, C and D).

\section{Growth and development of embryos:}

The concentrations of casein hydrolysate and paclobutrazol were significantly affected on all the studied characteristics of the somatic embryos in comparison with control (Table.2). Results showed that the period to somatic embryos formation was decreased with increasing concentrations of casein hydrolysate or paclobutrazol. The addendum of $1000 \mathrm{mg} . \mathrm{L}^{-1}$ casein hydrolysate and $0.5 \mathrm{mg} . \mathrm{L}^{-1}$ paclobutrazol showed fewer periods " 21.00 and 17.00 days" to embryo formation, respectively. While, the treatment of control observed the longest period (61.00 days) to somatic embryo formation. Results also showed that the number, length, diameter, fresh and dry weight of embryos were increased with increasing concentrations of casein hydrolysate and paclobutrazol in comparison with control. Both treatments, $1000 \mathrm{mg} . \mathrm{L}^{-1}$ casein hydrolysate and $1.0 \mathrm{mg} . \mathrm{L}^{-1}$ paclobutrazol showed the highest values of studied characteristics including: 6.50 and $1.60 \mathrm{~cm}$ length, 0.87 and $0.80 \mathrm{~cm}$ diameter, 0.366 and $0.361 \mathrm{gm}$ fresh weight and, 0.022 and 0.033 gm dry weight of embryo, respectively (Plate.1, E, F, G and H). Furthermore, two treatments of paclobutrazol $\left(0.5\right.$ and $\left.0.7 \mathrm{mg} . \mathrm{L}^{-1}\right)$ showed high number of embryos (16.33 and 16.67 embryos), respectively, when compared with other treatments of both casein and paclobutrazol. In contrast, the treatment of control demonstrated fewer values in these characteristics $(4.33$ embryos, $0.80 \mathrm{~cm}$ length, $0.13 \mathrm{~cm}$ diameter, $0.035 \mathrm{gm}$ fresh weight and $0.005 \mathrm{gm}$ dry weight of embryo). A paclobutrazol when added to MS medium has led to the inhibition of gibberellins and enhanced the ability to re-differentiation of callus cells stimulating for the formation of somatic embryos (Ogas et al., 1997; Subotic et al., 2009). The results 
of paclobutrazol agreed with results of other previous studies (Wu et al., 2004; Igielski \& Kepczynska, 2012). Or, the reason may be due to high concentrations of casein hydrolysate it gave the best results which they considered as a source of energy and amino acids that stimulate the formation, growth and development of somatic embryos from callus (Zhong et al., 1991; Ageel \& Elmeer, 2011). The results of casein hydrolysate treatments agreed with results of the other previous studies on date palm (Ageel \& Elmeer, 2011; Khierallah and Hussein, 2013), (Table.2 and Plate.1, E, F, G and H).

\section{Germination of somatic embryos:}

Results from Table.3 show significant increase of the percentage of germination with increasing concentrations of casein hydrolysate concentrations (Plate.2, I). However, the period of embryo germination were decreased with the increasing of casein hydrolysate concentrations (Plate.2, K). In addition, the treatment of casein hydrolysate at $1000 \mathrm{mg} . \mathrm{L}^{-1}$ showed the highest percentage of germination and less period of embryo germination ( $76 \%$ and 15.30 days, respectively) in comparison with other treatments $\left(0.0,200,400,600\right.$ and $\left.800 \mathrm{mg} . \mathrm{L}^{-1}\right)$. These results agreed with findings of other studies on in vitro culture of date palm (Ageel \& Elmeer, 2011; Ibrahim, 2012).

Moreover, a low concentration of paclobutrazol $\left(0.3 \mathrm{mg} . \mathrm{L}^{-1}\right)$, showed the highest percentage of germination $(75.67 \%)$ in comparison with other treatments $(0.0,0.5$, 0.7, 0.9 and $1.0 \mathrm{mg} . \mathrm{L}^{-1}$ ) of paclobutrazol (Plate. 2 , $\mathrm{J}$ and L). While, the $0.3 \mathrm{mg} . \mathrm{L}^{-1}$ concentration of paclobutrazol observed the lowest period of embryo germination (14.0 days) in comparison with the other concentrations of paclobutrazol. The control treatment showed the lowest percentage of germination and longest period of germination of embryo (23.33\% and 61.70 days), respectively (Table.3). These results agreed with results of study on Medicago trucatula (Igielski \& Kepczynska, 2012). (Table.3 and Plate.2)

\section{Indirect adventitious shoots formation:}

Results from table (3) shows formations of indirect adventitious shoots when the callus was cultured on MS medium supplemented with 800 or 1000 mg.L $\mathrm{L}^{-1}$ casein hydrolysate (Plate 2, M and N). However, no adventitious shoot were recorded with MS medium contained other concentrations of casein hydrolysate $(0.0,200,400$ and $\left.600 \mathrm{mg} . \mathrm{L}^{-1}\right)$, and paclobutrazol $\left(0.0,0.3,0.5,0.7,0.9\right.$ and $\left.1.0 \mathrm{mg} . \mathrm{L}^{-1}\right)$. These results may be due to the re-differentiation of callus cells by medium components and surrounding environmental conditions. Such differentiated cells are promeristemoids that grow and develop into adventitious buds (Torrey, 1967, Plessner et al., 1990). Results of the study agreed with the results of other studies on organogenesis from callus when it cultured on MS medium supplemented with high concentration ( 800 or $1000 \mathrm{mg} . \mathrm{L}^{-1}$ ) of casein hydrolysate (Piqueras et al., 1999; Vari, 2010), (Table.3 and Plate.2, M and N). 


\section{CONCLUSIONS}

Results from the present study can be concluded by the observing effective roles of casein hydrolysate and paclobutrazol in the induction and growth of the primary and embryogenic callus, the formation and germination of embryos.

\section{REFERENCES}

Abo-Zaid, A.N. (2000). Plant Hormones and Agricultural Applications. Arabic House for Publishing and Printing, Second edition, The Egyptian Arabic Republic. [In Arabic].

Ageel, S., Elmeer, K. (2011). Effects of casein hydrolysates and glutamine on callus and somatic embryogenesis of date palm (Phoenix dactylifera L.). New York Sci. J., 4(7):121-125.

Al-Baker A. (1972). [Date palm past and present, the new in the cultivation, industry and trade]. Al-Ani Press, Baghdad, Iraq, pp. 1085. [In Arabic].

Al-Khalifa A. A. S. (2007). [Study of effect of plant growth regulators and some medium components on adventitious bud initiation from date palm (Phoenix dactylifera L. cv. Barhee) callus in vitro culture]. (PhD Thesis), College of Agriculture, University of Basrah, Iraq, pp. 150.

Anderson, J. W. (1978). Sulpher in biology. The camelot press Ltd., Southampton. Great Britain.

Ibrahim, N.H.H. (2012). Some factors affecting the initiation of embryogenic callus of date palm (Phoenix dactylifera L.) cv. Breem, and randomized multiplication indices RAPD. M.Sc. Thesis. College of Agriculture, University of Baghdad, Iraq.[In Arabic].

Igielski, R., Kepczynska, E. (2012). The effect of $\mathrm{GA}_{3}$ and paclobutrazol on somatic embryogenesis in Msdicago trucatula Gaertn. Developmental Biology Plant 42: 270-273 .

Khierallah, H. S. M., Hussein, N. H. (2013). The role of coconut water and casein hydrolysate in somatic embryogenesis of date palm and genetic stability detection using RAPD markes. Research in Biotechnology, 4(3):20-28.

Murashige T., Skoog F. A. (1962). Revised medium for rapid growth and bioassays with tobacco tissue cultures. Physiologia Plantarum, 15:473-497.

Muter A. M. (1991). [Date palm cultivation and production]. Dar Al-Hikmah Press. Basrah University, Iraq, pp. 230. [In Arabic].

Ogas, J., Chen, J. T., Sung, S. R., Somerville, C. (1997). Cellular differentiation regulated by gibberellins in Arabidopsis thaliana pickle mutouf. Journal of Science, 227: 417- 423.

Piqueras, A., Han, B. H., Escribano, J., Rubio, C., Hellin, E., Fernandez, J. A. (1999). Development of cormogenic nodules and microcorms by tissue culture, a new tool for the multiplication and genetic improvement of saffron. Agronomy Journal, 19:603-610. 
Plessner, O., Ziv, M., Neghbi, M. (1990). In vitro corm production in the saffron crocus (Crocus sativus L.). Plant Cell, Tissue and Organ Culture, 26:89-

Rudus. I., Kepcznska, E., Kepczynski, J. J. (2002). Regulation of Medicageo sativa L. somatic embryogenesis by gibberellins. Plant Growth Regulators, 36 (1) :91-95.

Snedecor G. M., Cochran W. G. (1986). Statistical Methods. 9th ed., The Iowa State University, American Press, Iowa, U.S.A., pp. 507.

Subotic, A., Jevremovic, S., Trifunovic, M., Petric, M., Milosevic, S., Grubisic, D. (2009). The influence of gibberllic acid and paclobutrazol on induction of somatic embryogenesis in wild type and hairy root cultures of Centaurium erythraea Gillib. African Journal of Biology, 8(4):3223

Torrey, J. G. (1967). Development in Flowering Plant. The Macmillan Company, New York. pp 112-134.

Vari, E. S. (2010). Evaluation and optimizations of media on the tissue culture system of upland rice. Inter. Journal of Agriculture Biotechnology, 12(4): 537-540.

Wu, I.F., Chen, J. T., Chang, W.C. (2004). Effects of auxins and cytokinins on embryo formation from root-derived callus of Oncidium 'Gower Ramsey'. Plant Cell, Tissue and Organ Culture, 77:107-109.

Zhong, H., Srinivasan, C., Sticken, M.B.(1991). Plant regeneration via somatic embryogenesis in creeping bent grass (Agrostis palustris Huds.). Plant Cell Reports, 10: 453- 456.

Table 1: Effect of casein hydrolysate or paclobutrazol on fresh and dry weight of primary and embryogenic calli of date palm cv. Nersy.

\begin{tabular}{|c|c|c|c|c|c|}
\hline \multirow[t]{2}{*}{ Treatment } & \multirow{2}{*}{$\begin{array}{l}\text { Concentration } \\
\left(\mathrm{mg} \cdot \mathrm{L}^{-1}\right)\end{array}$} & \multicolumn{2}{|c|}{ Primary callus } & \multicolumn{2}{|c|}{ Embryogenic callus } \\
\hline & & $\begin{array}{c}\text { Fresh } \\
\text { weight } \\
\text { (gm.) }\end{array}$ & $\begin{array}{c}\text { Dry } \\
\text { weight } \\
\text { (gm.) }\end{array}$ & $\begin{array}{c}\text { Fresh } \\
\text { weight } \\
\text { (gm.) }\end{array}$ & $\begin{array}{c}\text { Dry } \\
\text { weight } \\
\text { (gm.) }\end{array}$ \\
\hline Control & 0.0 & 0.195 & 0.020 & 0.257 & 0.019 \\
\hline \multirow{5}{*}{$\begin{array}{c}\text { Casein } \\
\text { hydrolysate }\end{array}$} & 200 & 0.285 & 0.031 & 0.371 & 0.026 \\
\hline & 400 & 0.370 & 0.033 & 0.549 & 0.043 \\
\hline & 600 & 0.490 & 0.043 & 0.741 & 0.063 \\
\hline & 800 & 0.690 & 0.057 & 1.021 & 0.074 \\
\hline & 1000 & 1.103 & 0.098 & 1.280 & 0.095 \\
\hline \multirow{5}{*}{ Paclobutrazol } & 0.3 & 0.227 & 0.023 & 0.537 & 0.051 \\
\hline & 0.5 & 0.568 & 0.055 & 0.905 & 0.066 \\
\hline & 0.7 & 0.699 & 0.072 & 1.083 & 0.087 \\
\hline & 0.9 & 0.938 & 0.085 & 1.258 & 0.090 \\
\hline & 1.0 & 1.271 & 0.113 & 1.567 & 0.119 \\
\hline \multicolumn{2}{|c|}{ R-LSD P $\geq 0.05$} & 0.155 & 0.010 & 0.0189 & 0.0030 \\
\hline
\end{tabular}


Table 2: Effect of casein hydrolysate or paclobutrazol on embryo formation of date palm cv. Nersy.

\begin{tabular}{|c|c|c|c|c|c|c|c|}
\hline Treatment & $\begin{array}{l}\text { Concentrati } \\
\text { on }\left(\mathrm{mg} \cdot \mathrm{L}^{-1}\right)\end{array}$ & $\begin{array}{l}\text { Perio } \\
\mathrm{d} \text { of } \\
\text { embr } \\
\text { yo } \\
\text { forma } \\
\text { tion } \\
\text { (days) }\end{array}$ & $\begin{array}{l}\text { Avera } \\
\text { ge } \\
\text { Numb } \\
\text { er of } \\
\text { Embr } \\
\text { yos }\end{array}$ & $\begin{array}{l}\text { Lengt } \\
\mathrm{h} \text { of } \\
\text { Embr } \\
\text { yo } \\
(\mathrm{cm})\end{array}$ & $\begin{array}{l}\text { Diam } \\
\text { eter } \\
\text { of } \\
\text { Embr } \\
\text { yo } \\
(\mathrm{cm})\end{array}$ & $\begin{array}{l}\text { Fresh } \\
\text { weigh } \\
\text { t } \\
\text { (gm.) }\end{array}$ & $\begin{array}{c}\text { Dry } \\
\text { weigh } \\
\mathrm{t} \\
\text { (gm.) }\end{array}$ \\
\hline Control & & 61.00 & 4.33 & 0.80 & 0.13 & 0.035 & 0.005 \\
\hline \multirow{5}{*}{$\begin{array}{c}\text { Casein } \\
\text { hydrolysa } \\
\text { te }\end{array}$} & 200 & 55.33 & 5.67 & 2.53 & 0.27 & 0.208 & 0.013 \\
\hline & 400 & 48.00 & 6.00 & 3.23 & 0.63 & 0.212 & 0.016 \\
\hline & 600 & 39.33 & 7.33 & 5.50 & 0.67 & 0.224 & 0.019 \\
\hline & 800 & 26.00 & 9.67 & 6.10 & 0.77 & 0.269 & 0.022 \\
\hline & 1000 & 21.00 & 10.67 & 6.50 & 0.87 & 0.336 & 0.022 \\
\hline \multirow{5}{*}{$\begin{array}{c}\text { Paclobutr } \\
\text { azol }\end{array}$} & 0.3 & 21.67 & 6.67 & 1.27 & 0.23 & 0.144 & 0.017 \\
\hline & 0.5 & 17.00 & 16.33 & 0.93 & 0.43 & 0.104 & 0.016 \\
\hline & 0.7 & 20.33 & 16.67 & 1.17 & 0.40 & 0.169 & 0.020 \\
\hline & 0.9 & 26.00 & 12.67 & 1.67 & 0.77 & 0.361 & 0.025 \\
\hline & 1.0 & 26.00 & 12.67 & 1.60 & 0.80 & 0.361 & 0.033 \\
\hline \multicolumn{2}{|c|}{ R-LSD $P \geq 0.05$} & 9.030 & 0.930 & 0.30 & 0.13 & 0.019 & 0.003 \\
\hline
\end{tabular}

Table 3: Effect of casein hydrolysate or paclobutrazol on embryo germination of date palm cv. Nersy.

\begin{tabular}{|c|c|c|c|}
\hline Treatment & $\begin{array}{l}\text { Concentration } \\
\left(\mathrm{mg} \cdot \mathrm{L}^{-1}\right)\end{array}$ & $\begin{array}{c}\text { Embryo } \\
\text { germination } \\
(\%)\end{array}$ & $\begin{array}{l}\text { Period of } \\
\text { embryo } \\
\text { germination } \\
\text { (days) }\end{array}$ \\
\hline Control & 0.0 & 23.33 & 61.7 \\
\hline \multirow{5}{*}{$\begin{array}{c}\text { Casein } \\
\text { hydrolysate }\end{array}$} & 200 & 41.67 & 42.7 \\
\hline & 400 & 52.33 & 35.0 \\
\hline & 600 & 63.67 & 25.0 \\
\hline & 800 & 71.33 & 19.3 \\
\hline & 1000 & 76.00 & 15.3 \\
\hline \multirow{5}{*}{ Paclobutrazol } & 0.3 & 75.67 & 14.0 \\
\hline & 0.5 & 73.00 & 17.3 \\
\hline & 0.7 & 62.33 & 26.3 \\
\hline & 0.9 & 53.00 & 48.7 \\
\hline & 1.0 & 44.00 & 51.7 \\
\hline \multicolumn{2}{|c|}{ R-LSD P $\geq 0.05$} & 5.97 & 4.83 \\
\hline
\end{tabular}




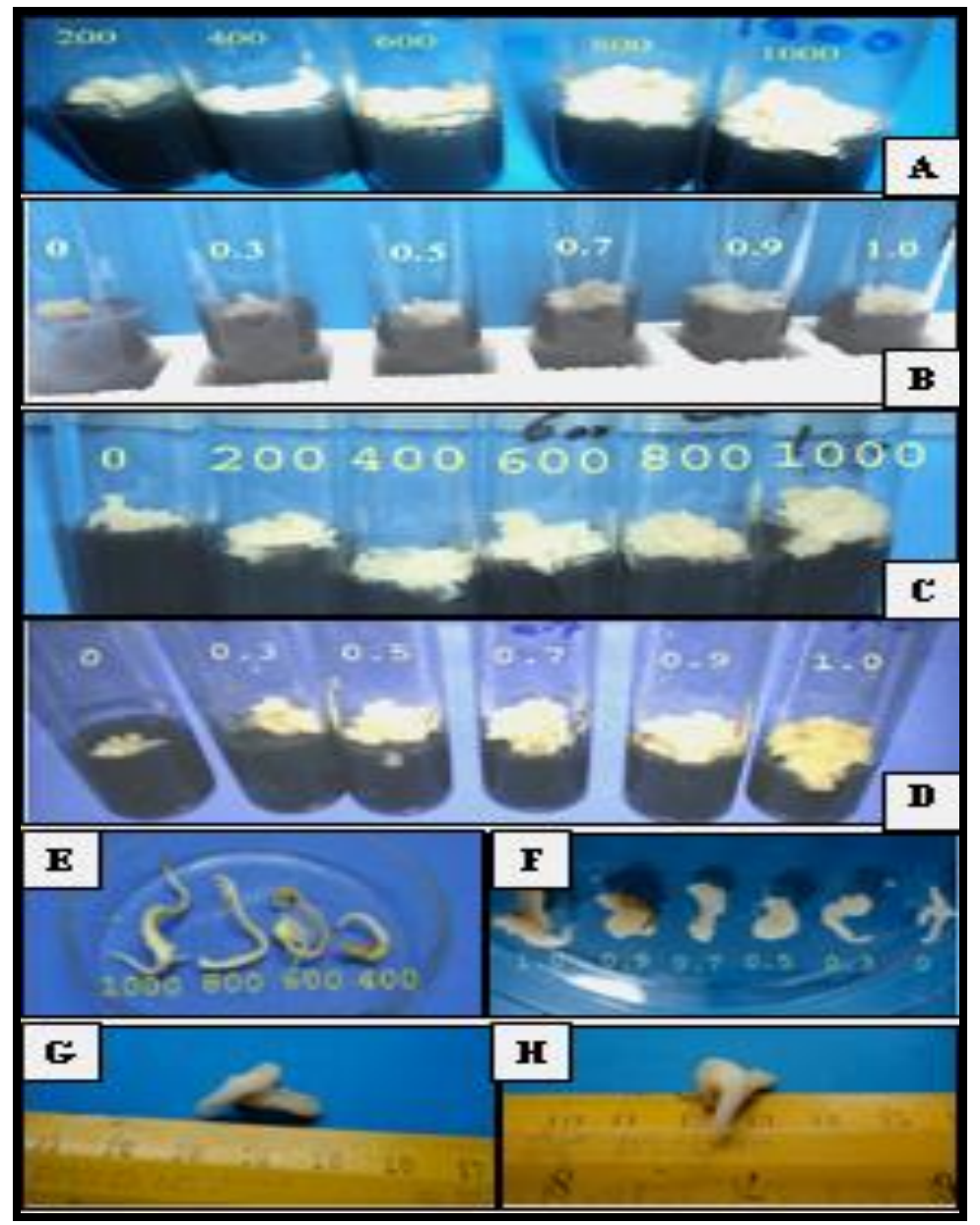

Plate 1: Micro propagation of date palm (Phoenix dactylifera L.).

*Callus induction on MS medium supplemented with different concentrations of casein hydrolysate (A), and paclobutrazol (B).

*Embryogenic callus on MS medium supplemented with different concentrations of casein hydrolysate (C), and paclobutrazol (D).

*Embryo formation on MS medium supplemented with different concentrations of casein hydrolysate (E), and paclobutrazol (F).

*Embryo length $(\mathrm{G})$, Embryo diameter $(\mathrm{H})$. 


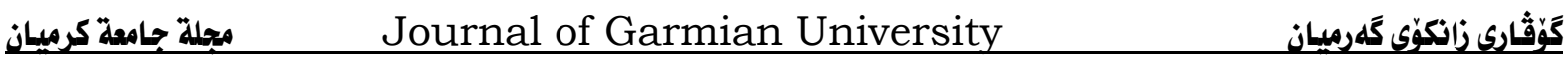

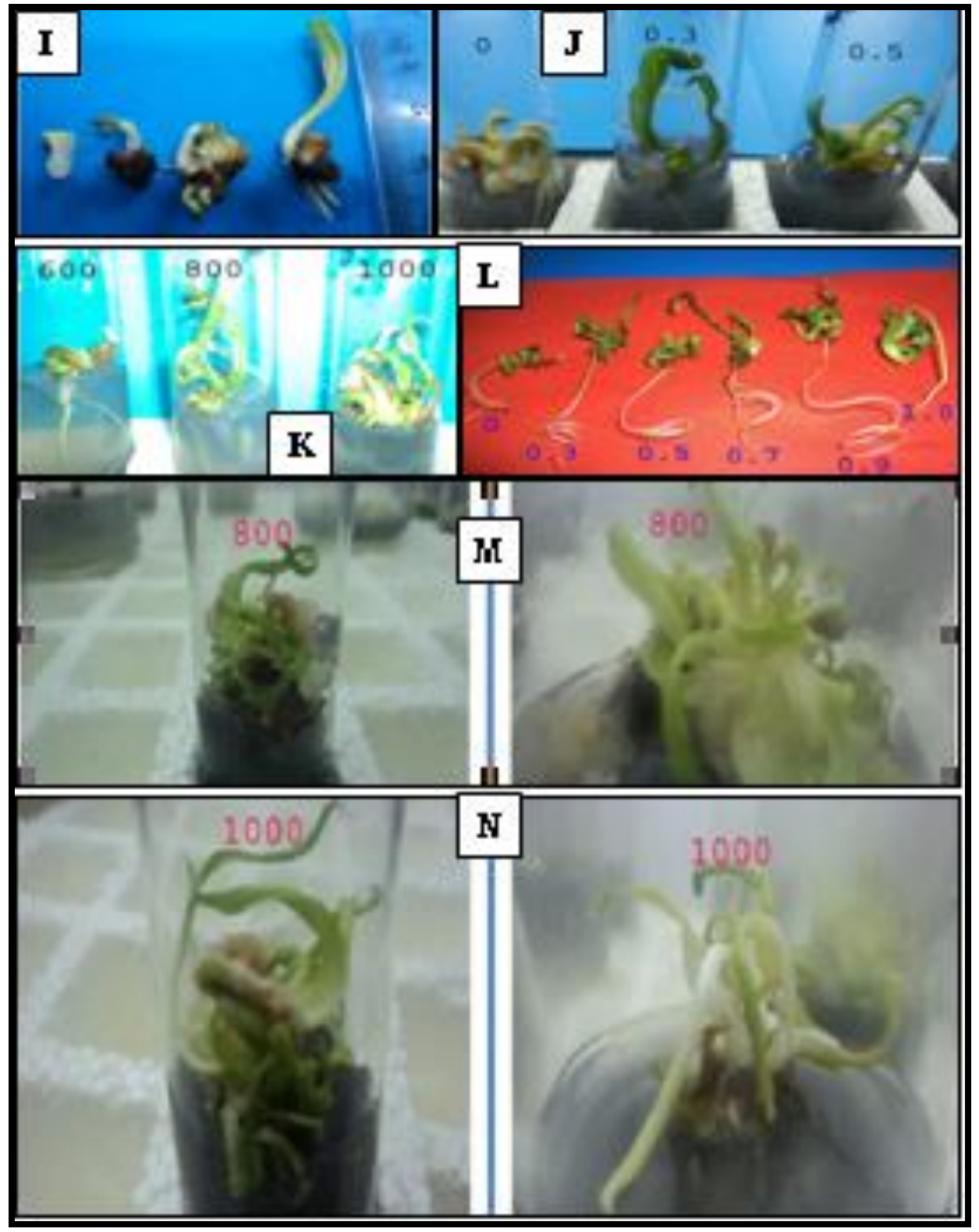

Plate 2: Stages of embryo germination (I)

*Germinated embryos on MS medium supplemented with different concentrations of casein hydrolysate $(\mathrm{K})$, and paclobutrazol ( $\mathrm{J}$ and $\mathrm{L})$.

*Formation of indirect adventitious shoots on MS medium supplemented with 800 $\mathrm{mg} . \mathrm{L}^{-1}$ or $1000 \mathrm{mg} . \mathrm{L}^{-1}$ casein hydrolysate (M and N). 